\title{
Pemetaan Usaha Cafe Di Manahan Dengan Menggunakan Metode Naive Bayes Studi Kasus Dinas Perdagangan
}

\author{
Paulus Harsadi ${ }^{1)}$; Dwi Remawati ${ }^{2)}$; Kriswantoro Budi Satrio ${ }^{3)}$ \\ 1) 2) 3) Program Studi Informatika, STMIK Sinar Nusantara \\ 1) paulusharsadi@sinus.ac.id; ${ }^{2)}$ dwirema@sinus.ac.id ; ${ }^{3)}$ tomkrisss@yahoo.com
}

\begin{abstract}
There are many cafes in Manahan, Surakarta. Café can be found almost in every street and it usually visits teenagers. In several years, businesses café grow rapidly in Manahan. Nowadays there are a lot of teenagers who have a habit of hanging out in the café. The purpose of this study is to build a mapping business café in Manahan using Naïve Bayer Method. It is caused to determine a large variable which has high potential for the surrounding point. It cannot be denied that using Naïve Bayes Method can help people to determine the mapping business café. The result of this study is arranged based on the lowest value which is consisting of micro, small and medium.
\end{abstract}

Keywords: Mapping, Naive Bayes, Application

\section{PENDAHULUAN}

Perkembangan teknologi di era globalisasi ini sangat pesat sekali, hampir disemua instansi ataupun di bidang industri menggunakan teknologi. Dengan adanya perkembangan teknologi yang sangat cepat menimbulkan perubahan yang sangat signifikan dalam berbagai bidang. Manfaat dari teknologi informasi dan komunikasi tidak dapat dipungkiri telah menggubah berbagai hal dalam bidang kehidupan manusia mulai dari lingkungan pribadi sampai dengan lingkungan instansi.

Di Manahan banyak menawarkan hidangan-hidangan kuliner mulai dari tradisional sampai internasional. Maka dari itu para pelaku bisnis berlomba-lomba membuka usaha di bidang kuliner. Usaha kuliner manahan ini pun sangat bermacam-macam mulai dari kafe atau coffe shop, angkringan, sampai pedagang kaki lima.

Dari latar belakang tersebut penulis ingin membuat Pemetaan Usaha Cafe Manahan Dengan Menggunakan Metode Naive Bayes. Penulis menggunakan metode tersebut dikarenakan Metode Naive Bayes, dapat menentukan daerah-daerah dalam suatu variabel yang memiliki potensi tinggi terhadap titik-titik di sekitarnya. Dalam pengklasifikasi pemetaan cafe berdasarkan karakteristiknya, penulis hanya akan menggunakan kreteria - kreteria sebagai berikut : Asset yang dimiliki, Omset yang dimiliki, dan jumlah tenaga kerja yang dimiliki oleh masing - masing Cafe.

\section{TINJAUAN PUSTAKA}

\subsection{Penelitian Sebelumnya}

Pada penelitian ini peneliti menggunakan beberapa referensi yang semuanya membahas tentang pemetaan peta dengan metode yang sama yaitu metode Naive Bayes untuk membandingkan perbedaan penelitian yang akan dibuat dengan penelitian yang sudah ada.

Prediksi Persediaan Obat Dengan Metode Naive Bayes [1]. Dalam penelitian ini membahas tentang menyatakan pada apotek saputro dalam pengolahan data obatnya masih menggunakan sistem manual dan belum dapat memprediksi stok obat.

Selanjutnya penelitian tentang Penerapan Data Mining Untuk Evaluasi Kinerja Akademik Mahasiswa Menggunakan Algoritma Naive Bayes Classifier [2]. Dalam penelitian ini pada tahun 2017 menyatakan penelitian ini di fokuskan untuk mengevaluasi kinerja akademik mahasiswa.

Selanjutnya penelitian tentang Sistem Pendukung Keputusan Menentukan Lokasi Rumah Makan Yang Strategis Menggunakan Metode Naive Bayes. Dalam penelitian ini masalah yang membahas Sistem Pendukung Keputusan untuk Menentukkan Lokasi Rumah Makan Yang Strategis Menggunakan Metode Naive Bayes untuk memudahkan masyarakat yang ingin membuka usaha rumah makan bisa terlebih dahulu menilai lokasi yang dipilih strategis atau kurang strategis untuk lokasi usaha rumah makan [3].

Selanjutnya penelitian tentang Sistem Informasi Geografis Usaha Mikro Kecil Dan Menengah (CAFE) Di Kota Padang Berbasis 
Web. Dalam penelitian ini masalah yang dibahas tentang Sistem Informasi Geografis untuk pemetaan lokasi Usaha Mikro Kecil dan Menengah (CAFE) di kota Padang. Penelitian tersebut menginformasikan mengenai gambaran peta data dimana letak lokasi industri CAFE dan menampilkan data berupa foto, nama, alamat dan keterangan dari industri yang ada di kota Padang [4].

\subsection{Konsep Rencana Bisnis}

Memulai bisnis tanpa merancang rencana bisnis adalah seperti menyetir dari Jakarta ke Bali tanpa menggunakan peta. Hal ini tentu dapat dilakukan oleh si pengemudi untuk mencapai tujuannya. Akan tetapi, dengan menggunakan peta tentu perjalanan dari Jakarta ke Bali akan lebih singkat dan menyenangkan. Terlebih lagi dalam memulai sebuah bisnis, memulai suatu bisnis dapat saja dilakukan tanpa menggunakan rencana bisnis terlebih dahulu. Akan tetapi, membangun sebuah bisnis dengan merancang rencana bisnis terlebih dahulu tentu akan memudahkan pebisnis dalam menjalankannya di kemudian hari. Rencana bisnis selalu harus berkembang menyesuaikan analisa SWOT bisnis yang dimiliki sehingga bisa di kembangkan perancangan model bisnis baru [5]. Salah satunya dengan mempertimbangkan competitor lain.

Langkah untuk memetakan competitor dapat digunakan sebagai salah satu acuan dalam penentuan strategi bisnis.

\subsection{Metode Naive Bayes}

Naive Bayes merupakan sebuah pengklasifikasian probalistik sederhana yang menghitung sekumpulan probabilitas dengan menjumlahkan frekuensi dan kombinasi nilai dari dataset yang diberikan. Algoritma menggunakan teorema bayes dan mengansumsikan semua atribut independen atau tidak saling ketergantungan yang diberikan oleh nilai pada variabel kelas. Naive Bayes juga didefinisikan sebagai pengklasifikasian dengan metode probabilitas dan statistik yang dikemukakan oleh ilmuan inggis Thomas Bayes [6], yaitu memprediksi peluang di masa depan berdasarkan pengalaman di masa sebelumnya.

Naive Bayes didasarkan pada asumsi penyederhanaan bahwa nilai atribut secara kondisional saling bebas jika diberikan nilai output. Dengan kata lain, diberikan nilai output, probabilitas mengamati secara bersama adalah produk dari probabilitas individu.

Keuntungan penggunaan Naive Bayes adalah bahwa metode ini hanya membutuhkan jumlah data pelatihan (Training Data) yang kecil untuk menentukan estimasi parameter yang diperlukan dalam proses pengklasifikasian. Naive Bayes sering bekerja jauh lebih baik dalam kebanyakan situasi dunia nyata yang komplek dari pada yang diharapkan [7].

Langkah - langkah metode Naive Bayes sebagai berikut:

$$
\mathrm{P}(\mathrm{H} \mid \mathrm{X})=\frac{P(X \mid H \cdot P(H)}{P(H)} .
$$

\section{Dimana :}

1) $X$ : data dengan class yang belum diketahui

2) $\mathrm{H}$ : hipotesis data menggunakan suatu class spesifik

3) $\mathrm{P}(\mathrm{H} \mid \mathrm{X})$ : probabilitas hipotesis $\mathrm{H}$ berdasar kondisi $\mathrm{X}$ (parteriori probabilitas)

4) $P(H)$ : probabilitas hipotesis $H$ (prior probabilitas)

5) $\mathrm{P}(\mathrm{X} \mid \mathrm{H})$ : probabilitas $X$ bedasarkan kondisi pada hipotesis $\mathrm{H}$

6) $P(X)$ : probabilitas $X$

\section{METODE PENELITIAN}

Langkah-langkah yang dikerjakan dalam penelitian sebagai berikut:

a. Perancangan Sistem

Suatu fase dimana di perlukan suatu keahlian perencanaan untuk elemenelemen komputer yang akan menggunakan sistem baru. Penulis akan membuat desain sistem yang terdiri dari beberapa tahapan.

b. Diagram Konteks

Digunakan untuk menggambarkan aplikasi klasifikasi CAFE yang dijabarkan secara keseluruhan. Pada sistem klasifikasi CAFE di Manahan dalam penerapan diagram konteks dapat digambarkan bahwa pengguna website dan admin merupakan terminator entity luar yang berinteraksi dengan lingkaran proses tunggal di dalamnya terdapat sistem klasifikasi CAFE menggunakan metode Naïve Bayes dan akan memeperlihatkan sebuah proses yang berinteraksi dengan lingkungannya yang menyampaikan aliran data dari komponenkomponen sistem yang menunjukkan 
sumber data, tujuan data, dan proses penyimpanan data

c. HIPO

Pembuatan HIPO dirancang secara khusus untuk menggambarkan suatu struktur dan desain dalam membangun sistem aplikasi, yang bertujuan untuk menghasilkan output yang benar dan dapat memenuhi kebutuhan user, dalam pembuatan HIPO memerlukan tahapan pembuatan yaitu menentukan top level, level 0, level 1.

\section{d. Diagram Alir Data}

Model logika data atau proses yang dibutuhkan untuk menggambarkan dari mana asal data dan kemana tujuan data yang keluar dari sistem, dimana data disimpan, proses apa yang menghasilkan data tersebut dan interaksi antara data yang tersimpan dan proses yang dikenakan pada data terebut. Pada sistem perancangan diagram alir data yang akan diterapkan pada sistem klasifikasi CAFE di Manahan, terdapat user dan administrator sebagai entity luar yang merupakan sumber atau tujuan dari aliran data dari atau ke sistem.

e. Desain Database

Perancangan database digunakan untuk merancang penyimpanan data dari inputan yang dimasukan pada Sistem Aplikasi Klasifikasi dan Pemetaan CAFÉ di Manahan. Pada penelitian ini perancangan database yang digunakan menggunnakan MySQL dan menggunakan metode perancangan database Entity Relationship Diagram (ERD)

f. Desain Input

Desain input menggambarkan bagaimana antarmuka untuk pengguna berinteraksi dengan mengisi formulir yang digunakan sebagai dasar untuk memasukkan data ke dalam sistem.

Perancangan input diantaranya :

1. Desain input login admin

2. Desain input CAFÉ

g. Desain Output

Desain output menggambarkan bagaimana antarmuka keluaran berupa informasi yang didapat dari hasil masukan pengguna sebelumnya. Perancangan output tersebut diantaranya : Desain output hasil klasifikasi dalam bentuk pemetaan.

\section{IV.HASIL DAN PEMBAHASAN}

\subsection{Perhitungan Metode Naive Bayes}

Berikut pemetaan cafe dengan metode naive bayes pada Tabel 1 .

Tabel 1. Data testing perhitungan klasifikasi

\begin{tabular}{|c|l|l|l|c|c|c|c|c|}
\hline No & Nama & Alamat & $\begin{array}{l}\text { Jenis } \\
\text { Cafe }\end{array}$ & K1 & K2 & K3 & K4 & K5 \\
\hline 1. & $\begin{array}{l}\text { Cafe } \\
2\end{array}$ & $\begin{array}{l}\text { Jalan } \\
\text { AdiSucip } \\
\text { to }\end{array}$ & $\begin{array}{l}\text { Outd } \\
\text { oor }\end{array}$ & $<50$ & $<50$ & $<5$ & $\begin{array}{l}\text { Live } \\
\text { Music }\end{array}$ & $\begin{array}{l}\text { Mik } \\
\text { ro }\end{array}$ \\
\hline
\end{tabular}

Keterangan :

Kolom No= Merupakan Kolom Alternatif yaitu Penomoran

Kolom Nama = Merupakan Kolom Alternatif yaitu Nama Cafe

Kolom Alamat $=$ Merupakan Kolom Alternatif yaitu Alamat Cafe

Kolom Jenis Cafe = merupakan kolom kriteia ke

Kolom $\mathrm{K} 1=$ merupakan kolom kriteria ke 1 yaitu Aset

Kolom K2 = merupakan kolom kriteria ke 2 yaitu Omset

Kolom K3 = merupakan kolom kriteria ke 3 yaitu Tenaga Kerja

Kolom K4 = Merupakan Kolom Alternatif ke 4 yaitu Fasilitas

Kolom K5 = Merupakan Kolom Alternatif ke 5 yaitu Kriteria

1. Identifikasi kriteria

Dalam penerapan metode Naive Bayes untuk pemetaan ada 4 kriteria yang telah ditentukan yaitu Aset, Omset, Tenaga Kerja, Fasilitas. Keempat kriteria ini diperoleh dari data yang di ambil dari dinas perdagangan.

2. Normalisasi Bobot Kriteria

Setelah didapat bobot setiap kriteria, kemudian dilakukan proses normalisasi, yaitu dengan membagi atara bobot kriteria dengan jumlah seluruh bobot kriteria dengan menggunakan persamaan (1).

1. Menghitung Jumlah label/class

$P=(Y=$ Mikro $)=11 / 20$

$\mathrm{P}=(\mathrm{Y}=$ Kecil $)=7 / 20$

$P=(Y=$ Menengah $)=2 / 20$

2. Menghitung jumlah Kasus yang sama dengan class yang sama

$\mathrm{P}=(\mathrm{JK}=$ Indoor $\mid \mathrm{Y}=$ Mikro $)=7 / 11$

$P=(\mathrm{JK}=$ Indoor $\mid Y=$ Kecil $)=5 / 7$

$\mathrm{P}=(\mathrm{JK}=$ Indoor $\mid \mathrm{Y}=$ Menengah $)=1 / 2$

$\mathrm{P}=$ (Omset 50-100jt $\mid \mathrm{Y}=$ Mikro) $=5 / 11$

$\mathrm{P}=($ Omset 50-100jt $\mid \mathrm{Y}=$ Kecil $)=6 / 7$ 


$$
\begin{aligned}
& \mathrm{P}=(\text { Omset 50-100jt } \mid \mathrm{Y}=\text { Menengah })=0 / 2 \\
& \mathrm{P}=(\text { Aset 50-300jt } \mid \mathrm{Y}=\text { Mikro }=0 / 11 \\
& \mathrm{P}=(\text { Aset 50-300jt } \mid \mathrm{Y}=\text { Kecil }=6 / 7 \\
& \mathrm{P}=(\text { Aset 50-300jt } \mid \mathrm{Y}=\text { Menengah }=0 / 2 \\
& \mathrm{P}=(\text { Tenaga Kerja } 5-10 \mid \mathrm{Y}=\text { Mikro }=0 / 11 \\
& \mathrm{P}=(\text { Tenaga Kerja 5-10 } \mid \mathrm{Y}=\text { Kecil }=1 / 7 \\
& \mathrm{P}=(\text { Tenaga Kerja 5-10 } \mid \mathrm{Y}=\text { Menengah }= \\
& 0 / 2 \\
& \mathrm{P}=\text { (Fasilitas=Live Music } \mid \mathrm{Y}=\text { Mikro }= \\
& 11 / 11 \\
& \mathrm{P}=(\text { Fasilitas=Live Music } \mid \mathrm{Y}=\text { Kecil }=6 / 7 \\
& \mathrm{P}=\text { (Fasilitas=Live Music } \mid \mathrm{Y}=\text { Menengah }= \\
& 1 / 2
\end{aligned}
$$

3. Menghitung nilai likelihood

Menghitung nilai likelihood dengan mengalikan semua hasil variable mikro, kecil, dan menengah :

Mikro $=\mathrm{P}($ Indoor $/$ mikro $)$ * $\mathrm{P}$ (omset 50 $300 \mathrm{jt} / \mathrm{mikro})$ * $\mathrm{P}$ (asset $50-500 \mathrm{jt} / \mathrm{mikro})$ * $\mathrm{P}$ (tenaga kerja 5-10/mikro) * $\mathrm{P}($ Fasilitas $=$ Live Musik/mikro) * $\mathrm{P}$ (mikro)

$=\frac{7}{11} \times \frac{5}{11} \times \frac{0}{11} \times \frac{0}{11} \times \frac{11}{11} \times \frac{11}{20}$

$=0.6363 \times 0,4545 \times 0 \times 0 \times 1 \times 0,55=0$

Kecil $=\mathrm{P}($ Indoor $/$ kecil $) * \mathrm{P}($ omset $50-$ 300jt/kecil) * $\mathrm{P}$ (asset $50-500 \mathrm{jt} / \mathrm{kecil})$ * $\mathrm{P}$ (tenaga kerja 5-10/kecil) * $\mathrm{P}$ (Fasilitas=Live Musik/kecil)* $\mathrm{P}$ (kecil)

$=\frac{5}{7} \times \frac{6}{7} \times \frac{6}{7} \times \frac{1}{7} \times \frac{5}{7} \times \frac{7}{20}$

$=0,7142 \times 0,8571 \times 0,8571 \times 0,1428 \times 0,7142$ $\mathrm{x} 0,35=0,0187$

Menengah $=\mathrm{P}($ Indoor/menengah) * $\mathrm{P}$ (omset 50-300jt/menengah) * $\mathrm{P}$ (asset 50500jt/menengah) * $\mathrm{P}$ (tenaga kerja 5$10 /$ menengah $)$ * $P($ Fasilitas $=$ Live Musik/menengah) * $\mathrm{P}$ (menengah)

$=\frac{1}{2} x \frac{0}{2} \times \frac{0}{2} \times \frac{0}{2} \times \frac{0}{2} \times \frac{2}{20}$

$=0,5 \times 0 \times 0 \times 0 \times 0 \times 0 \times 0,2=0$

\section{Mencari Probability}

Mencari Probability label/class Mikro, Kecil, dan Menengah untuk membandingkan kemungkinan yang lebih besar

$$
\begin{array}{r}
\text { Mikro }=\frac{0}{(0+0,0187+0)}=\frac{0}{0,0187} \\
=0 \times 100 \%=0
\end{array}
$$

$$
\begin{aligned}
& \text { Menengah }=\frac{0}{(0+0,0187+0)} \\
& =\frac{0}{0,0187}=0 \times 100 \%=0 \\
& \begin{aligned}
& \text { Kecil }=\frac{0,0187}{0+0,0187+0} \\
&=\frac{0,0187}{0,0187} \\
&=1 \times 100 \%=100 \%
\end{aligned}
\end{aligned}
$$

Terlihat bahwa nilai probabilitas tertinggi ada pada kelas (P|Kecil) dengan nilai probabilitas sebanyak $100 \%$, sehingga dapat disimpulkan bahwa tingkatan usaha dari data testing atas nama Cafe Mom Milk tersebut masuk dalam klasifikasi "Usaha Kecil”

\subsection{Perancangan Sistem}

\section{Diagram Konteks}

Diagram konteks merupakan hubungan antara keluaran atau masukan data yang menjadi satu kesatuan antara dalam sistem

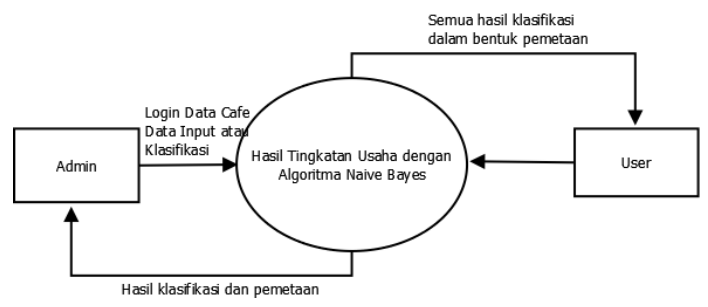

Gambar 1 Diagram Konteks

\section{Hierarchy Input Proses Output}

HIPO atau bagian berjenjang untuk mempersiapkan penggambaran DAD untuk menuju level di bawahnya.

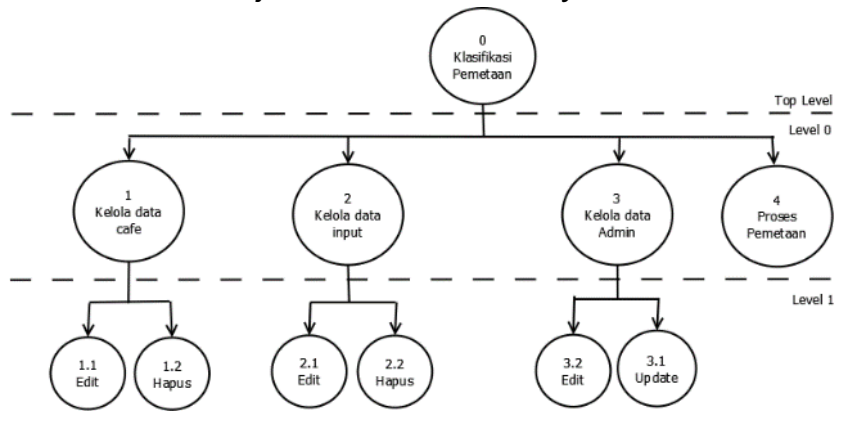

Gambar 2. Diagram HIPO

\subsection{Implementasi}

Implementasi sistem pada penelitian ini menggunakan aplikasi berbasis web. Sistem dibangun dengan bahasa pemrograman PHP dan MySQL sebagai layanan database. Sistem dibangun secara offline. 
Halaman Login berfungsi untuk masuk ke dalam halan admin.

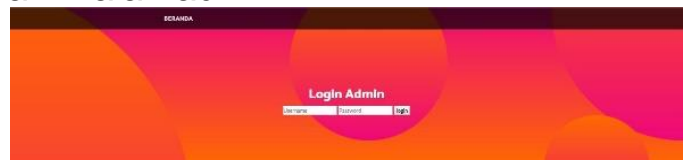

Gambar 3. Halaman Login Admin.

\subsubsection{Halaman Training}

Halaman Training berfungsi untuk menampilkan data training yang akan diinputkan.

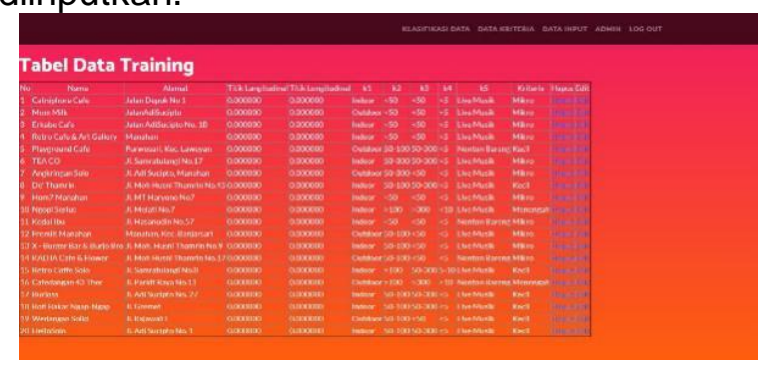

Gambar 4. Halaman Training

\subsubsection{Halaman Input Data}

Halaman Input Data berfungsi untuk menampilkan data yang akan di input pada form training.

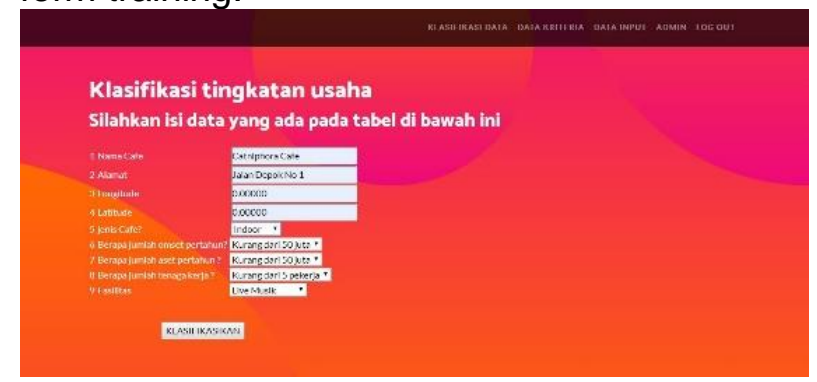

Gambar 5. Halaman Input Data.

\subsubsection{Halaman Input}

Halaman Input Merupakan Data Hasil dari input data yang berasal dari form training.

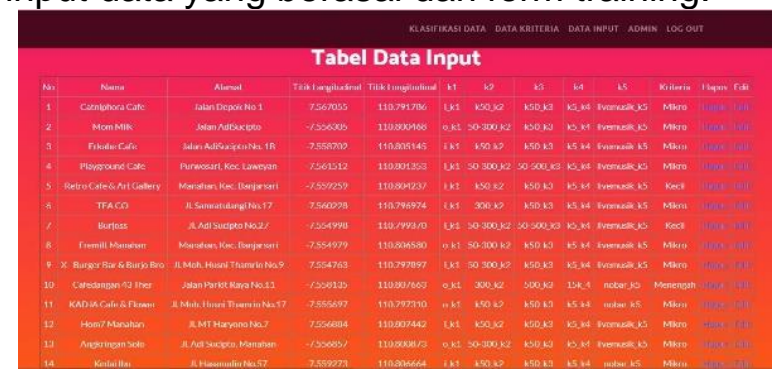

Gambar 6. Halaman Input.

\subsubsection{Halaman Kategori}

Halaman Kategori merupakan halaman yang menampilkan data hasil proses pemetaan berupa mikro, kecil, dan menengah.

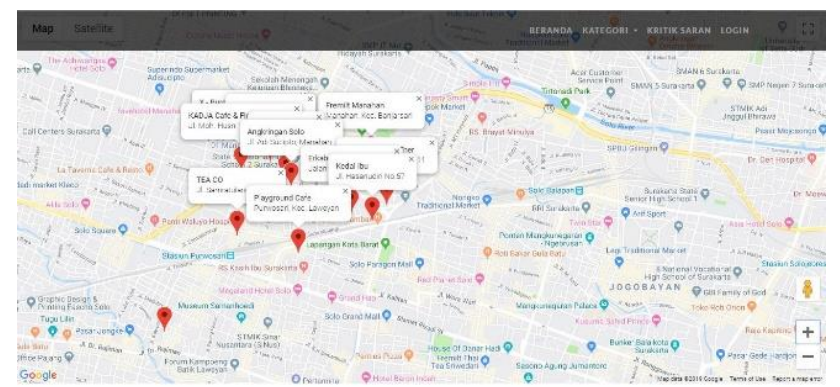

Gambar 7. Halaman Kategori

\section{2.}

\section{Pengujian Sistem}

Pengujian bertujuan untuk menemukan kesalahan-kesalahan serta kekurangan pada sistem. Pada pengujian ini, penulis melakukan uji Fungsional dan uji validitas.

\subsection{1.}

Uji Fungsional

Pengujian fungsionalitas aplikasi pemetaan ini menggunakan metode black box, pengujian berfokus pada persyaratan fungsional perangkat lunak, untuk mendapatkan serangkaian kondisi input yang sesuai dengan persyaratan fungsional suatu program.

Berdasarkan pengujian fungsionalitas pada sistemdapat disimpulkan bahwa semua kompone - komponen yang terdapat dalam aplikasi perangkingan dapat digunakan dan difungsikan sesuai dengan tujuannya.

\subsubsection{Uji Validitas}

Pengujian secara validitas membahas tentang kebenaran cara perhitungan sistem yang menggunakan algoritma Naïve Bayes sebagai dasar penentuan keadaan yang dituangkan ke dalam sebuah bahasa pemrograman untuk membuat hasil perhitungan yang dapat dipakai oleh pengguna. Pada pengujian validitas ini akan di dapatkan akurasi dari algoritma Naïve Bayes dalam masalah yang peneliti bahas.

Tabel 2. Hasil Perhitungan Sistem Algoritma Naive Bayes

\begin{tabular}{|c|c|c|c|c|c|c|c|c|}
\hline $\begin{array}{l}\mathbf{N} \\
\mathrm{O}\end{array}$ & $\begin{array}{l}\text { Nam } \\
\text { a } \\
\text { Cafe }\end{array}$ & Alamat & $\begin{array}{c}\text { Jeni } \\
\text { s } \\
\text { Caf } \\
\text { e } \\
\text { (k1) }\end{array}$ & $\begin{array}{c}\text { Oms } \\
\text { et } \\
\text { (juta/ } \\
\text { thn) } \\
\text { (k2) }\end{array}$ & $\begin{array}{l}\text { Aset } \\
\text { (juta/ } \\
\text { thn) } \\
\text { (k3) }\end{array}$ & $\begin{array}{c}\text { Ten } \\
\text { aga } \\
\text { Kerj } \\
\text { a } \\
(\mathbf{k} 4)\end{array}$ & $\begin{array}{l}\text { Fasil } \\
\text { itas } \\
\text { (k5) }\end{array}$ & $\begin{array}{c}\text { Skala } \\
\text { Usah } \\
\text { a }\end{array}$ \\
\hline 1 & $\begin{array}{l}\text { Cafe } \\
1\end{array}$ & $\begin{array}{l}\text { Jalan Depok } \\
\text { No } 1\end{array}$ & $\begin{array}{l}\text { Indo } \\
\text { or }\end{array}$ & $<50$ & $<50$ & $<5$ & $\begin{array}{l}\text { Live } \\
\text { Musi } \\
\text { c } \\
\end{array}$ & Mikro \\
\hline 2 & $\begin{array}{l}\text { Cafe } \\
2\end{array}$ & $\begin{array}{l}\text { Jalan } \\
\text { AdiSucipto }\end{array}$ & $\begin{array}{l}\text { Out } \\
\text { door }\end{array}$ & $<50$ & $<50$ & $<5$ & $\begin{array}{l}\text { Live } \\
\text { Musi } \\
\text { c } \\
\end{array}$ & Mikro \\
\hline 3 & $\begin{array}{l}\text { Cafe } \\
3\end{array}$ & $\begin{array}{l}\text { Jalan } \\
\text { AdiSucipto } \\
\text { No. 1B } \\
\end{array}$ & $\begin{array}{l}\text { Indo } \\
\text { or }\end{array}$ & $<50$ & $<50$ & $<5$ & $\begin{array}{l}\text { Live } \\
\text { Musi } \\
\text { c } \\
\end{array}$ & Mikro \\
\hline 4 & $\begin{array}{l}\text { Cafe } \\
4\end{array}$ & $\begin{array}{l}\text { Manahan, } \\
\text { Kec. } \\
\text { Banjarsari }\end{array}$ & $\begin{array}{l}\text { Indo } \\
\text { or }\end{array}$ & $<50$ & $<50$ & $<5$ & $\begin{array}{l}\text { Live } \\
\text { Musi } \\
\text { c }\end{array}$ & Mikro \\
\hline 5 & Cafe & Purwosari, & Out & $50-$ & $50-$ & $<5$ & Nont & Kecil \\
\hline
\end{tabular}




\begin{tabular}{|c|c|c|c|c|c|c|c|c|}
\hline $\begin{array}{l}\mathbf{N} \\
\mathbf{O}\end{array}$ & $\begin{array}{c}\text { Nam } \\
\text { a } \\
\text { Cafe }\end{array}$ & Alamat & $\begin{array}{c}\text { Jeni } \\
\text { s } \\
\text { Caf } \\
e \\
(k 1)\end{array}$ & $\begin{array}{l}\text { Oms } \\
\text { et } \\
\text { (juta/ } \\
\text { thn) } \\
\text { (k2) }\end{array}$ & $\begin{array}{c}\text { Aset } \\
\text { (juta/ } \\
\text { thn) } \\
\text { (k3) }\end{array}$ & $\begin{array}{c}\text { Ten } \\
\text { aga } \\
\text { Kerj } \\
\text { a } \\
(\mathbf{k} 4)\end{array}$ & $\begin{array}{l}\text { Fasil } \\
\text { itas } \\
(k 5)\end{array}$ & $\begin{array}{c}\text { Skala } \\
\text { Usah } \\
\text { a }\end{array}$ \\
\hline & 5 & $\begin{array}{l}\text { Kec. } \\
\text { Laweyan }\end{array}$ & door & 100 & 300 & & $\begin{array}{l}\text { on } \\
\text { Bare } \\
\text { ng }\end{array}$ & \\
\hline 6 & $\begin{array}{l}\text { Cafe } \\
6\end{array}$ & $\begin{array}{l}\text { Jl. } \\
\text { Samratulan } \\
\text { gi No.17 }\end{array}$ & $\begin{array}{l}\text { Indo } \\
\text { or }\end{array}$ & $\begin{array}{l}50- \\
300\end{array}$ & $<50$ & $<5$ & $\begin{array}{l}\text { Live } \\
\text { Musi } \\
\text { c }\end{array}$ & Mikro \\
\hline 7 & $\begin{array}{l}\text { Cafe } \\
7\end{array}$ & $\begin{array}{l}\text { Jl. Adi } \\
\text { Sucipto, } \\
\text { Manahan }\end{array}$ & $\begin{array}{l}\text { Out } \\
\text { door }\end{array}$ & $\begin{array}{l}50- \\
300\end{array}$ & $<50$ & $<5$ & $\begin{array}{l}\text { Live } \\
\text { Musi } \\
\text { c }\end{array}$ & Mikro \\
\hline 8 & $\begin{array}{l}\text { Cafe } \\
8\end{array}$ & $\begin{array}{l}\text { Jl. Moh. } \\
\text { Husni } \\
\text { Thamrin } \\
\text { No.45 }\end{array}$ & $\begin{array}{l}\text { Indo } \\
\text { or }\end{array}$ & $\begin{array}{l}50- \\
100\end{array}$ & $\begin{array}{l}50- \\
300\end{array}$ & $<5$ & $\begin{array}{l}\text { Live } \\
\text { Musi } \\
\text { c }\end{array}$ & Kecil \\
\hline 9 & $\begin{array}{l}\text { Cafe } \\
9\end{array}$ & $\begin{array}{l}\text { JI. MT } \\
\text { Haryono } \\
\text { No.7 } \\
\end{array}$ & $\begin{array}{l}\text { Indo } \\
\text { or }\end{array}$ & $<50$ & $<50$ & $<5$ & $\begin{array}{l}\text { Live } \\
\text { Musi } \\
\text { c }\end{array}$ & Mikro \\
\hline 10 & $\begin{array}{l}\text { Cafe } \\
10\end{array}$ & $\begin{array}{l}\text { Jl. Melati } \\
\text { No.7 }\end{array}$ & $\begin{array}{l}\text { Indo } \\
\text { or }\end{array}$ & $>100$ & $>300$ & $>10$ & $\begin{array}{l}\text { Live } \\
\text { Musi } \\
\text { c }\end{array}$ & $\begin{array}{l}\text { Mene } \\
\text { ngah }\end{array}$ \\
\hline 11 & $\begin{array}{l}\text { Cafe } \\
11\end{array}$ & $\begin{array}{l}\text { Jl. } \\
\text { Hasanudin } \\
\text { No. } 57\end{array}$ & $\begin{array}{l}\text { Indo } \\
\text { or }\end{array}$ & $<50$ & $<50$ & $<5$ & $\begin{array}{l}\text { Nont } \\
\text { on } \\
\text { Bare } \\
\text { ng }\end{array}$ & Mikro \\
\hline 12 & $\begin{array}{l}\text { Cafe } \\
12\end{array}$ & $\begin{array}{l}\text { Manahan, } \\
\text { Kec. } \\
\text { Banjarsari }\end{array}$ & $\begin{array}{l}\text { Out } \\
\text { door }\end{array}$ & $\begin{array}{l}50- \\
100\end{array}$ & $<50$ & $<5$ & $\begin{array}{l}\text { Live } \\
\text { Musi } \\
\mathrm{c} \\
\end{array}$ & Mikro \\
\hline 13 & $\begin{array}{l}\text { Cafe } \\
13\end{array}$ & $\begin{array}{l}\text { Jl. Moh. } \\
\text { Husni } \\
\text { Thamrin } \\
\text { No.9 }\end{array}$ & $\begin{array}{l}\text { Indo } \\
\text { or }\end{array}$ & $\begin{array}{l}50- \\
100\end{array}$ & $<50$ & $<5$ & $\begin{array}{l}\text { Live } \\
\text { Musi } \\
\text { c }\end{array}$ & Mikro \\
\hline 14 & $\begin{array}{l}\text { Cafe } \\
14\end{array}$ & $\begin{array}{l}\text { Jl. Moh. } \\
\text { Husni } \\
\text { Thamrin } \\
\text { No.17 }\end{array}$ & $\begin{array}{l}\text { Out } \\
\text { door }\end{array}$ & $\begin{array}{l}50- \\
100\end{array}$ & $<50$ & $<5$ & $\begin{array}{l}\begin{array}{l}\text { Nont } \\
\text { on } \\
\text { Bare } \\
\text { ng }\end{array} \\
\end{array}$ & Mikro \\
\hline 15 & $\begin{array}{l}\text { Cafe } \\
15\end{array}$ & $\begin{array}{l}\text { Jl. } \\
\text { Samratulan } \\
\text { gi No.8 }\end{array}$ & $\begin{array}{l}\text { Indo } \\
\text { or }\end{array}$ & $>100$ & $\begin{array}{l}50- \\
300\end{array}$ & $\begin{array}{l}05 \sim \\
10\end{array}$ & $\begin{array}{l}\text { Live } \\
\text { Musi } \\
\text { c }\end{array}$ & Kecil \\
\hline
\end{tabular}

$$
\begin{gathered}
\text { Accuracy }=\frac{\text { jumlah True }}{\text { Jumlah True }+ \text { Jumlah False }} \times 100 \% \\
=\frac{12}{15} \times 100 \%=80 \%
\end{gathered}
$$

Perbandingan antara data testing dan data hasil perhitungan naïve dapat menghasilkan akurasi dengan rincian kebenaran sebanyak $80 \%$.

\section{PENUTUP}

\subsection{Kesimpulan}

Berdasarkan masalah yang diuraikan dan pembahasan yang dilakukan penulis. Penulis dapat menyimpulkan beberapa hal dan saran, kesimpulan yang dapat ditarik dalam penelitian ini ialah:

1. Terwujudnya sistem klasifikasi tingkatan usaha untuk mengklasifikasikan data CAFE baru dengan hasil akhir berupa prosentasi nilai kemungkinan mikro, kecil, atau menengah.

2. Berdasarkan uji akurasi penggunaan metode Naïve Bayes sebesar $80 \%$.

\subsection{Saran}

Sistem klasifikasi tingkatan usaha dengan metode Naïve Bayes telah selesai dibuat dan untuk pengembangan penelitian berikutnya, maka perlu kiranya peneliti memberikan saran:
1. Sistem klasifikasi ini mengambil kasus Cafe yang terdapat Di Manahan, dapat dikembangkan untuk atau di daerah lain.

2. Sistem klasifikasi ini menggunakan data training CAFE dengan jumlah data training 20 data, agar mendapatkan akurasi yang lebih tinggi maka dapat dimungkinkan untuk menambahkan jumlah data training yang lebih banyak.

\section{DAFTAR PUSTAKA}

[1] M. Furqan, S. H. Wibowo, and D. Abdullah, "Sistem Persediaan Obat Padapuskesmas Menggunakan Metode Naïve Bayes (Studi Kasus Puskesmas Talang Tinggi Seluma)," J. Tek. Inform. Univ. muhamadiyah bengkulu, pp. 1-10, 2016.

[2] M. S. Mustafa, M. R. Ramadhan, and A. P. Thenata, "Implementasi Data Mining untuk Evaluasi Kinerja Akademik Mahasiswa Menggunakan Algoritma Naive Bayes Classifier," reat. Inf. Technol. J., vol. 4, no. 2, p. 151, 2018.

[3] A. Yusnita and R. Handini, "Sistem Pendukung Keputusan Menentukan Lokasi Rumah Makan yang Strategis Menggunakan Metode Naive Bayes," Semin. Nas. Teknol. Inf. Komun. Terap. 2012, vol. 2012, no. Semantik, pp. 290-294, 2012.

[4] Minarni and Delfia, "Sistem Informasi Geografis Usaha Mikro Kecil Dan Menengah ( UMKM) Di Kota Padang Berbasis Web," J. Momentum, vol. 18, no. 1, pp. 1-10, 2016.

[5] D. H. Jackson, Andy, "Evaluasi Dan Perancangan Model Bisnis Padda Kaisar Organizer Dengan Business Model Canvas," IImiah, vol. 3, no. 1, p. 8, 2015.

[6] Kevin P. Murphy, "Naive Bayes Classifiers," Univ. Br. Columbia, vol. 18, pp. 371-381, 2006.

[7] K. Vembandasamy, R. Sasipriya, and E. Deepa, "Heart Diseases Detection Using Naive Bayes Algorithm," Int. J. Innov. Sci. Eng. Technol., vol. 2, no. 9, pp. 441-444, 2015. 